\title{
Physiotherapeutic approach for pain and quality of life of a hemophilic patient. Case report
}

\author{
Abordagem fisioterápica na dor e na qualidade de vida de um indivíduo com artrite hemofílica. \\ Relato de caso
}

Matheus Santos Gomes Jorge ${ }^{1}$, Igor Schreiner Moreira², Gabriel Felimberti², Lia Mara Wibelinger ${ }^{3}$

DOI 10.5935/1806-0013.20160016

\section{ABSTRACT}

BACKGROUND AND OBJECTIVES: Hemophilia is a congenital, uncommon and chronic coagulopathy characterized by recurrent hemarthrosis outbreaks. It affects predominantly males and produces major musculoskeletal disorders, such as movement limitation, joint fibrosis, hemarthrosis and tissue hemorrhages, muscle contractures, muscle strength deficit and hemophilic arthritis, resulting in pain and impaired quality of life. This study aimed at evaluating the effects of a physiotherapeutic intervention program on pain and quality of life of a patient with hemophilic arthritis.

CASE REPORT: Male patient, 23 years old, with hemophilic arthritis. His major complaint was pain in different body sites, especially in ankles and right knee. Pain was evaluated with the visual analog scale and body pain map, and quality of life was evaluated with the Short-Form Health Survey questionnaire. Patient was submitted to eight physiotherapy sessions, once a week, with mean duration of 50 minutes, between May and June 2015. Adopted intervention protocol was based on conventional kinesiotherapy.

CONCLUSION: This study has shown that a physiotherapy program based on kinesiotherapy has decreased the number of tender points and pain intensity, as well as has improved quality of life of a patient with hemophilic arthritis.

Keywords: Hemophilia A, Hemophilia B, Pain, Physiotherapy, Quality of life.

\section{RESUMO}

JUSTIFICATIVA E OBJETIVOS: A hemofilia é uma coagulopatia congênita, rara e crônica, caracterizada pelos surtos recidivantes de hemartroses. Predomina no gênero masculino e produz agravos osteomioarticulares importantes como restrição dos movimentos, fibrose articular, hemartroses e hemorragias tissulares, contraturas musculares, déficit de força muscular e artrite hemofílica, resultando em quadros de dor e piora na qualidade de vida. O objetivo deste estudo foi verificar os efeitos de um programa fisioterápico de intervenção na dor e na qualidade de vida de um indivíduo com artrite hemofílica.

RELATO DO CASO: Paciente do gênero masculino, 23 anos de idade, com diagnóstico de artrite hemofílica. Sua queixa principal era a dor em diversos pontos do corpo, especialmente em tornozelos e joelho direito. A dor foi avaliada através da escala analógica visual e do mapa de dor corporal, e a qualidade de vida por meio questionário Short-Form Health Survey. O paciente foi submetido a oito sessóes de fisioterapia, uma vez por semana, com duração média de 50 minutos, entre os meses de maio a junho de 2015. O protocolo de intervenção adotado baseou-se em cinesioterapia convencional.

CONCLUSÃO: O presente estudo demonstrou que um programa de fisioterapia baseado na cinesioterapia diminuiu o número de pontos dolorosos e a intensidade da dor, bem como melhorou os domínios da qualidade de vida em um indivíduo com artrite hemofílica.

Descritores: Dor, Fisioterapia, Hemofilia A, Hemofilia B, Qualidade de vida.

\section{INTRODUCTION}

Hemophilia is a congenital disease caused by blood coagulation factor deficiency and characterized by recurrence of hermarthroses, especially in joints. It has two forms: type A (factor VIII deficit) or type B (factor IX deficit) ${ }^{1}$.

Males are more frequently affected, with its peak between 20 and 29 years of age, being that type $A$ is the most frequent $^{2}$. Worldwide, 6.9 million people have some hemorrhagic disorder ${ }^{3}$ and in Brazil almost 11 thousand people had some type of hemophilia in 2012. In this same period, Rio Grande do Sul had slightly more than 600 cases of the disease ${ }^{2}$.

Hemophilic patients have persistent pain, which varies from moderate to severe. In this population, pain may induce mus-

2. Universidade de Passo Fundo, Passo Fundo, RS, Brazil.

Submitted in November 26, 2015.

Accepted for publication in January 27, 2016.

Conflict of interests: none - Sponsoring sources: none.

Correspondence to:

Matheus Santos Gomes Jorge

BR 285 - Bairro São José

99052-900 Passo Fundo, RS, Brasil.

E-mail: mathjorge5@gmail.com

(C) Sociedade Brasileira para o Estudo da Dor
}

3. Universidade de Passo Fundo, School of Physiotherapy. Passo Fundo, RS, Brazil. 
culoskeletal complications ${ }^{4}$, such as joint movement limitation, joint fibrosis, contractures, gait and muscle strength changes, hemarthroses, tissue hemorrhage and hemophilic arthritis (HA) ${ }^{1,5}$. Due to coagulation process changes, hemorrhages are the most frequent complications of hemophilic patients and may be spontaneous or secondary to trauma ${ }^{6}$.

There is currently consensus among health care professionals about the use of physiotherapy for hemophilic individuals because it corrects motor deficits, improves functionality, decreases pain and improves quality of life $(\mathrm{QL})^{1}$. Regular exercises aim at better psychosocial conditions, increase or maintenance of muscle strength and trophism, joint mobility and stability, flexibility, balance and functionality, thus improving daily life activities (DLA) ${ }^{7,8}$. Different physiotherapeutic modalities are welcome to treatment, especially kinesiotherapy ${ }^{7,8}$. However, literature still lacks sources discussing and exploring the best physiotherapeutic treatment for hemophilic patients 1,5,7. $^{1}$.

In light of the above, this study aimed at observing the effects of a physiotherapeutic program on pain and QL of a hemophilic arthritis patient.

\section{CASE REPORT}

This is a longitudinal, interventionist, case report study. It is part of an umbrella project called "Effects of physiotherapy on patients with rheumatic diseases", approved by the Ethics Committee for Research with Human Beings of the Universidade de Passo Fundo under protocol 348.381, according to Resolution 196/96 of the National Health Council (NHC).

Male patient, 23 years old, with HA, who participated in 8 physiotherapy sessions from May to June 2015, once a week lasting approximately one hour in the Physiotherapy Clinic of the School of Physical Education and Physiotherapy, Universidade de Passo Fundo, Passo Fundo/RS after signing the Free and Informed Consent Term (FICT).

Baseline evaluation consisted in data collection (age, profession, physical evaluation and others), QL evaluation by means of the quality of life questionnaire - Medical Outcomes Study 36 - Item Short-Form Health Survey (SF-36), translated and validated for the Portuguese language, and pain evaluation by means of the body map of pain and the visual analog scale (VAS), all carried out as interviews after previous explanation of the procedures and the answering of questions. SF-36 is a 36-item scale gathering physical (functional capacity, physical aspects, pain and general health status) and mental (vitality, social aspects, emotional aspects and mental health) components. The higher the score, the better the health-related QL?

Body map of pain is a representation of the human body where patients indicate specific site and distribution of pain at evaluation time ${ }^{10}$. VAS is a horizontal straight line with edges numbered from zero (no pain) to 10 (worst imaginable pain). Patients should quantitatively indicate their pain at that moment ${ }^{11}$.
Intervention protocol was based on global conventional kinesiotherapy with emphasis on lower limbs, and aimed at muscle strengthening, mobility, balance, proprioception and gait training by means of weight bearing. The order of exercises was: initial and final blood pressure measurement; global active and/or passive stretching of major upper and lower limbs and trunk muscle groups (for 15 seconds); joint mobilization of ankles, bilateral metatarsi, feet phalanges, right knee, left hip, left elbow and lumbar and cervical spine; squeeze a proprioceptive ball with feet $(3 \times 10)$; sitting and standing holding $2 \mathrm{~kg}$ anklets $(3 \times 10)$; mini-squats in airex, progressing to discoball (3/x010); plantiflexion with 2 $\mathrm{kg}$ shin guards, progressing to $3 \mathrm{~kg}(3 \times 10)$; kicking a futsal ball with $2 \mathrm{~kg}$ shin guards, progressing to $2.5 \mathrm{~kg}$ (10 kicks with each leg, in three series); going up and downstairs with $3 \mathrm{~kg}$ shin guards ( $3 \times 15$ steps); ergonomic bike with load 3 , progressing to load 5 (during 10 minutes). Session was closed with ankles cryotherapy for 20 minutes. The number of loads and repetitions was established according to patient's physical conditions and has maintained the same value throughout the treatment. All parameters were revaluated after 8 physiotherapy sessions.

Table 1 shows data related to individual's QL before and after physiotherapy, according to SF-36.

There has been considerable improvement in limitation by physical aspects, followed by pain, social aspects and limitation by emotional aspects, while remaining domains have maintained the same value or have not shown satisfactory results.

Table 2 shows data regarding patient's pain, according to body map of pain and VAS.

Table 1. Quality of life before and after physiotherapeutic intervention, according to SF-36

\begin{tabular}{lcc}
\hline Domains & $\begin{array}{c}\text { Before } \\
\text { intervention }\end{array}$ & $\begin{array}{c}\text { After } \\
\text { intervention }\end{array}$ \\
\hline Functional capacity & 100 & 100 \\
Limitation by physical aspects & 0 & 50 \\
Pain & 20 & 74 \\
General health status & 82 & 82 \\
Vitality & 50 & 30 \\
Social aspects & 62.5 & 100 \\
Limitation by emotional aspects & 66.6 & 100 \\
Mental health & 96 & 88 \\
\hline
\end{tabular}

Table 2. Pain before and after physiotherapy, according to body map of pain and visual analog scale

\begin{tabular}{|c|c|c|}
\hline & Before intervention & After intervention \\
\hline Pain site & $\begin{array}{l}\text { Cervical region } \\
\text { Lumbar region } \\
\text { Left elbow } \\
\text { Right knee } \\
\text { Left thigh internal region } \\
\text { Right and left ankles }\end{array}$ & $\begin{array}{l}\text { Cervical region } \\
\text { Left ankle }\end{array}$ \\
\hline $\begin{array}{l}\text { General pain } \\
\text { intensity }\end{array}$ & 8 & 2 \\
\hline
\end{tabular}


Pain has considerably improved after physiotherapy, according to patient's report. Tender points, which initially were six, have decreased to just two, and general pain intensity has decreased 6 points, according to VAS.

\section{DISCUSSION}

Pain contributes to incapacity of chronic disease patients ${ }^{12}$, since in static contraction the activity of the painful muscle is decreased and attenuates synergist muscle activity, thus worsening pain ${ }^{13}$. Around $86 \%$ of hemophilia cases are followed by pain and from these $92 \%$ report arthralgia ${ }^{14}$. This is in line with our study because patient had joint pain complaint, especially in ankles and knees, which leads to incapacity and muscle unbalance, thus contributing to worsening pain.

In HA, recurrent hemarthroses lead to joint degeneration, joint deformities, severe functional deficiency, and consequently generating pain as described in this report ${ }^{15}$. HA patients have complications such as strength deficits and muscle atrophies, joint instability, hypomobility, proprioceptive decrease and limitation of biomechanical movements, thus making difficult pain relief ${ }^{16}$. Patient has reported using factor VIII concentrate and has maintained this therapy during physiotherapeutic treatment. This strategy associated to physiotherapy may decrease the duration of hemorrhages, generating better results and lower public expenditures ${ }^{17}$.

Some studies suggest that exercises increase the level of circulating factor VIII ${ }^{18}$ and when early performed provide positive results, such as decreased joint bleedings, pain relief, increased muscle strength and resistance and prevention of possible mioarticular deformities, assuring better QL and fitness to patients ${ }^{16}$. This is why we have chosen physical exercises as the intervention modality for this study.

Literature states that kinesiotherapy uses movement to provide mobility, flexibility, muscle coordination, to increase muscle strength and resistance to fatigue19. Due to joint instabilities it is necessary to encourage proprioceptive exercises aiming at joint balance and repositioning7, assuring a good development of muscles and protection of joints against new hemorrhagic events1. This is why exercises were performed with weight bearing, aiming at preventing the recurrence of hemarthroses, which are reasons for pain and impact on QL of HA patients. Evidences recommend that physiotherapy should be applied two to three times a week with minimum duration of three months20, which is in line with current study which has adopted a shorter intervention time and patient improved or maintained pain and QL.

A different study has evaluated the efficacy of two physiotherapeutic interventions in nine ankle HA patients. They were randomized in mobilization and stretching group (G1) and manual therapy group (G2).

At the end of 12 sessions, both groups have improved all ankle movements, being that $\mathrm{G} 1$ had better results regarding pain perception and $\mathrm{QL}^{21}$. In our study, patient has followed a protocol of exercises based on kinesiotherapy and has improved QL, especially limitation by physical aspects and pain. So, it is understood that physiotherapy may be an effective alternative to maintain or rehabilitate pain and QL of hemophilic patients, in addition to decreasing the financial impact of pharmacological therapies. So, as for the general population, hemophilic patients benefit from physical activity ${ }^{5}$. In our study, using similar techniques, such as joint mobilization and stretching, patient has improved QV and pain.

A case study with HA patient who performed 20 physiotherapy sessions, has involved global stretching, joint mobilization, strengthening exercises with load (resisted and isometric), weight transfer exercises, posture re-education and gait training. At the end, it was observed that QL had significantly improved $^{1}$, what is in line with current study because our patient has performed a protocol of kinesiotherapy-based exercises and has improved QL, especially in limitation by physical aspects and pain.

A different study has evaluated the efficacy of two physiotherapeutic interventions in nine ankle HA patients. They were randomized in mobilization and stretching group (G1) and manual therapy group (G2). At the end of 12 sessions, both groups have improved all ankle movements, being that G1 had better results regarding pain perception and $\mathrm{QL}^{21}$. In our study, using similar techniques, such as joint mobilization and stretching, patient has improved QL and pain.

A study has divided 31 ankle HA individuals in groups: manual therapy consisting in joint traction, passive stretching of gatrocnemius muscles, muscle strength and proprioception exercises (G1), educational and home exercises group (G2) and control group (G3). Study has lasted 12 weeks and G1 was better than G2 and G3 because it has improved muscle trophism and has decreased ankle pain ${ }^{22}$, which confirms our study because adopted intervention was effective for pain relief, especially ankle pain, according to patient's report, and has improved QL.

A case study with a male patient with knee and ankle HA, has performed physiotherapy for 8 weeks. Resources were Neuromuscular Proprioceptive Facilitation (NPF) techniques. Results have shown improved movement amplitude and decreased involved joint pain according to VAS ${ }^{23}$. In our study, kinesiotherapy was effective to improve pain of our patient.

\section{CONCLUSION}

A physiotherapeutic protocol based on kinesiotherapy was effective to decrease the number of tender points, to relieve pain and to improve quality of life of an individual with hemophilic arthritis.

\section{REFERENCES}

1. Bortolon AP, Sachetti A, Wibelinger LM. Análise da qualidade de vida de um indivíduo portador de artrite hemofílica: um estudo de caso. EFDeportes. 2012;17(169), Disponível em:<http://www.efdeportes.com/efd169/individuo-portador-de-artrite-hemofilica.htm>. Acesso em 10 de novembro de 2015.

2. Brasil. Ministério da Saúde. Secretaria de Atençáo à Saúde. Coordenaçăo-Geral de Sangue e Hemoderivados. Perfil das coagulopatias hereditárias no Brasil: 2011-2012 / Ministério da Saúde, Secretaria de Atenção à Saúde, Coordenação-Geral de Sangue e Hemoderivados. - Brasília: Ministério da Saúde, 2014.

3. Gonzalez, DC. La hemofilia: situación actual en Cuba y perspectivas. Rev Cubana Hematol Inmunol Hemoter. 2013;29(2):112-3. 
4. Lambing A, Kohn-Converse B, Hanagavadi S, Varma V. Use of acupuncture in the management of chronic haemophilia pain. Haemophilia. 2012;18(4):613-17

5. Querol F, Pérez-Alenda S, Gallach JE, Devís-Devís J, Valencia-Peris A, Moreno LM. Haemophilia: exercise and sport. Apunts Med Esport. 2011;46(169):29-39.

6. Gidaris D, Economou M, Valeri R, Gombakis N, Athanasiou-Metaxa M. Successful treatment of a spontaneous haemothorax with recombinant factor VIIa in a haemophilic child with inhibitors. Hippokratia. 2010;14(4):289-90.

7. Melo CC, Pereira CA, Formiga CK, Sandoval RA, Viana FP. Tratamento fisioterapêutico das alteraçóes musculoesqueléticas em pacientes com Hemofilia. Estudos, Goiânia. 2010;37(1/2):113-24.

8. Negrier C, Seuser A, Forsyth A, Lobet S, Llinas A, Rosas M, Heijnen L.The benefits of exercise for patients with haemophilia and recommendations for safe and effective physicalactivity. Haemophilia. 2013;19(4):487-98.

9. Burille A, Cervinski T, Vidmar MF, Wibelinger LM. Qualidade de vida de portadores de espondilite anquilosante submetidos a um programa de hidrocinesioterapia. EFDeportes. 2012;17(169). Disponível em: <http://www.efdeportes.com/efd169/espondilite-anquilosante-a-hidrocinesioterapia.htm>. Acesso em: 11 de novembro de 2015.

10. Wenngren A, Stalnacke BM. Computerized assessment of pain drawing area: a pilot study. Neuropsychiatr Dis Treat. 2009;5:451-56.

11. Martinez JE, Grassi DC, Marques LG. Análise da aplicabilidade de três instrumentos de avaliaçăo de dor em distintas unidades de atendimento: ambulatório, enfermaria e urgência. Rev Bras Reumatol. 2011;51(4):304-8

12. Simōes AS. A dor irruptiva na doença oncológica avançada. Rev Dor. 2011;12(2):166-71.

13. Falla D, Farina D, Dahl MK, Graven-Nielsen T. Muscle pain induces task-dependent changes in cervical agonist/antagonist activity. J Appl Physiol. 2007;102(2):601-9.

14. Kalnins W, Schelle G, Jost K, Eberl W, Tiede A. Pain therapy in haemophilia in Ger- many. Patient survey (BESTH study). Hamostaseologie. 2014;21(1):35.

15. Brasil. Ministério da Saúde. Secretaria de Atenção à Saúde. Departamento de Atençāo Especializada. Manual de reabilitação na hemofilia / Ministério da Saúde. Secretaria de Atenção à Saúde. Departamento de Atenção Especializada. Coordenação-Geral de Sangue e Hemoderivados. - Brasília : Ministério da Saúde, 2011.

16. Gomis M1, Querol F, Gallach JE, González LM, Aznar JA. Exercise and sport in the treatment of haemophilic patients: a systematic review. Haemophilia. 2009;15(1):43-54.

17. Júnior NS, Vieira WH. Meios físicos na reabilitaçấo do paciente portador de hemofilia. Uma revisão de literatura. Rev da FARN. 2010;9(1/2):197-210.

18. Andery SCA, Galatti LR, Alves MLT, Duarte E. Exercício físico e hemofilia: conceitos e intervenção. Revista Mackenzie de Educação Física e Esporte. 2005;11(2):96-109.

19. Florentino DM, De Sousa FR, Maiworn AI, Carvalho AC, Silva KM. A fisioterapia no alívio da dor: uma visão reabilitadora em cuidados paliativos. Rev Hosp. Univ Pedro Ernesto. 2012;11(2):50-7.

20. Stephensen D, Rodriguez-Merchan EC. Orthopaedic co-morbidities in the elderly haemophilia population: a review. Haemophilia. 2013;19(2):166-73.

21. Cuesta-Barriuso R, Gómez-Conesa A, López-Pina JA. Manual therapy in the treatment of ankle hemophilic arthropathy. A randomized pilot study. Physiother Theory Pract. 2014;30(8):534-9.

22. Cuesta-Barriuso R, Gómez-Conesa A, López-Pina JA. Effectiveness of two modalities of physiotherapy in the treatment of haemophilic arthropathy of the ankle: a randomized pilot study. Haemophilia. 2014;20(1):71-8.

23. Luterek M, Baranowski M, Zakiewicz W, Biel A, Pedzisz P. PNF-based rehabilitation in patients with severe haemophilic arthropathy-case study. Ortop Traumatol Rehabil. 2009;11(3):280-9. 